\title{
Ендоваскулярні оперативні втручання для корекції критичної ішемії нижніх кінцівок при синдромі стопи діабетика
}

\begin{abstract}
Мета роботи: проаналізувати можливості ендоваскулярної корекції стенотично-оклюзійних уражень артерій підколінногомілково-стопового сегмента при синдромі стопи діабетика та критичній ішемії нижніх кінцівок.

Матеріали і методи. Дослідження базується на аналізі результатів клінічного спостереження та лікування 87 хворих на синдром стопи діабетика з стенотично-оклюзійним ураженням артерій підколінно-гомілково-стопового сегмента та розвитком критичної ішемії нижніх кінцівок (середній вік хворих $(67,3 \pm 8,35)$ року). Основним показанням до виконання ендоваскулярних артеріальних втручань була ішемія нижньої кінцівки IVст. за Fontaine. Критерієм оцінки ефективності оперативного втручання у даному дослідженні вважали залишковий стеноз менше 30.

Результати досліджень та їх обговорення. Застосування ендоваскулярних втручань при стенотично-оклюзійних ураженнях артерій гомілки призводить до відновлення прохідності артерій і безпосереднього клінічного успіху в 94,3 \% спостережень. Несприятливими чинниками, що впливають на клінічний результат операції, є комбіноване ураження артерій гомілки та протяжність ураження артерій більше 5 см. Показання до виконання балонної ангіопластики можуть бути розширені при багаторівневих оклюзіях артерій у хворих з ішемічною формою стопи діабетика у випадках неможливості виконання відкритої реконструкції через тяжку супутню патологію, відсутність пластичного матеріалу або поширених трофічних змінах ураженої кінцівки.
\end{abstract}

Ключові слова: синдром стопи діабетика; стенотично-оклюзійні ураження судин; ендоваскулярні оперативні втручання; балонна ангіопластика; критична ішемія нижньої кінцівки.

Постановка проблеми і аналіз останніх досліджень та публікацій. Синдром стопи діабетика, або синдром діабетичної стопи (СДС), є найпоширенішою причиною інвалідизація при цукровому діабеті (ЦД) та основною причиною нетравматичних ампутацій. Облітеруючі захворювання периферійних судин, до яких відносять ураження судин кінцівок, за різними повідомлення, залежно від віку, раси та інших чинників, зустрічаються у 20-45 \% дорослого населення світу $[1,2]$. Лікування СДС та критичної ішемії нижніх кінцівок (КІНК) є вкрай складним. Тривала консервативна терапія сприяє зниженню ризику “високих” ампутацій та інколи дозволяє обмежитися локальним хірургічним втручанням (некректомія, “малі” ампутації, розтин флегмон чи абсцесу стопи) та відстроченню реконструктивних операцій. Однак вже упродовж першого року близько 20 \% хворих втрачає одну, а впродовж наступних років обидві нижні кінцівки $[3,4]$.

Це дає право стверджувати, що СДС та КІНК є першочерговими показаннями до реваскуляризуючих методів лікування. 3 метою запобігання розвитку ряду післяопераційних ускладнень у хворих реконструктивні хірургічні втручання слід проводити до розвитку останньої $[5,6]$. При виконанні відновних операцій необхідно враховувати багаторівневий характер оклюзії, особливості колатерального кровообігу, стан периферичного судинного русла, осо- бливості формування анастомозу та гемодинаміку, коморбідність та інші чинники, які мають вплив на вибір типу та етапності оперативного втручання [7].

У зв'язку з бурхливим розвитком ендоваскулярних методів реваскуляризації артерій малого діаметру і зокрема коронарної ангіопластики, 3'явилася можливість застосування цих методик в лікуванні стенотично-оклюзійних уражень (СОУ) дистальних артерій нижніх кінцівок у дещо видозміненому вигляді.

Мета роботи: проаналізувати можливості ендоваскулярної корекції стенотично-оклюзійних уражень артерій підколінно-гомілково-стопового сегмента при синдромі стопи діабетика та критичної ішемії нижніх кінцівок.

Матеріали і методи. При виконанні даного дослідження керувались загальноприйнятими світовими та вітчизняними нормами відповідно до основних положень: Директиви ЄЕС № 609 від 24.11.1986 р., GCР (1996р.), Конвенції Ради Європи про права людини та біомедицину (від 04.04.1997р.), Гельсінської декларації Всесвітньої медичної асоціації про етичні принципи проведення наукових медичних досліджень за участю людини (1964-2000рр.) і наказу МОЗ України № 281 від 01.11.2000 p.

Дослідження базується на аналізі результатів клінічного спостереження та лікування 87 хворих 
на СДС із стенотично-оклюзійних уражень артерій підколінно-гомілково-стопового сегмента та роз-

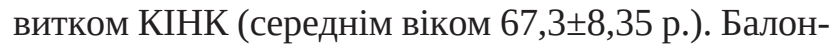
на ангіопластика (БАП) підколінної артерії (ПкА) та однієї артерії гомілки була виконана у 16, ПкА та двох артерій гомілки у 8, ПкА та трьох артерій гомілки у 3, тібіоперонеального стовбура (ТПС) та однієї артерії гомілки у 13, ТПС та двох артерій гомілки у 4, ТПС та трьох артерій гомілки у 2, однієї артерії гомілки у 21, двох артерій гомілки у 17, трьох артерії гомілки у 3. Основним показанням до виконання ендоваскулярних артеріальних втручань була ішемія нижньої кінцівки IV ст. за Fontaine. Перевагу эндоваскулярному втручанню віддавали у випадках тяжкого загального стану пацієнта з високим ризиком відкритого хірургічного втручання; поширення некротичних змін тканин стопи і гомілки з їх інфікуванням, з високою вірогідністю гнійно-септичних ускладнень у випадку відкритої реконструкції; при сегментарних СОУ артерій підколінно-гомілково-стопового сегмента зі збереженими шляхами відтоку до стопи; у випадку СОУ артерій підколінно-гомілково-стопового сегмента будь-якої протяжності за відсутності оклюзії на рівні стегно-підколіного сегменту і наявністю критичної ішемії. Загальноприйнятим критерієм успіху в ендоваскулярній хірургії вважається залишковий стеноз менше 30 \%, який i був узятий за основу оцінки ефективності оперативного втручання у даному дослідженні $[4,7]$.

Результати досліджень та їх обговорення. Ангіографічний або технічний успіх ендоваскулярних втручань, що призводить до істотно- го збільшення просвіту судини в зоні стенозу або оклюзії, ми отримали в 94,3 \% спостережень. Технічний успіх БАП ТПС і ПкА у поєднанні з БАП артерій гомілки спостерігався практично в усіх випадках, гірші ангіографічні результати отримано при втручаннях на декількох артеріях гомілки - 55,0-94,1 \% успішних ангіопластик (табл. 1).

Кращі результати отримано при виконанні ангіопластик артерій гомілки з приводу стенозів порівняно з оклюзіями (табл. 2).

Найбільш поширена причина невдалого ангіографічного результату БАП СОУ гомілкових артерій - технічна неможливість проходження зони оклюзійного ураження при спробах ії реканалізації (2 випадки), в одному випадку не вдалося провести провідник за зону стенозу. Хоча нам не вдалося відновити кровообіг, у цих пацієнтів клінічний стан кінцівок, що піддалися втручанню, в цілому не погіршився, оскільки компенсація була досягнута за рахунок одночасної ангіопластики інших артерій гомілки.

Під час операцій ускладнень і летальних результатів не було. У першу добу після операції ми проводили спостереження за станом нижніх кінцівок у спокої, а надалі при фізичному навантаженні. Ангіопластику вважали успішною у тих випадках, коли зникав біль у спокої, усувалися або зменшувалися явища переміжної кульгавості, відбувалося потепління шкірних покривів, з'являлася пульсація артерії дистальніше відновленого сегмента. Визначення Тср $0_{2}$ до і після ендоваскулярних реваскуляризацій проводилось 26 (29,9 \%) хворим. Середнє значення Тср0 до опе-



Таблиця 1. Залежність результату втручання від локалізації стенотично-оклюзійного ураження

\begin{tabular}{||l|c|c|c||}
\hline \multicolumn{1}{|c|}{ Локалізація ураження } & Кількість втручань & $\begin{array}{c}\text { Кількість успішних } \\
\text { втручань }\end{array}$ & $\begin{array}{c}\text { Успішних втручань } \\
\text { (\%) }\end{array}$ \\
\hline кА+одна артерія гомілки & 16 & 16 & 100 \\
\hline ПкА+дві артерії гомілки & 8 & 8 & 75,0 \\
\hline ПкА+три артерії гомілки & 3 & 2 & 100 \\
\hline ТПС+одна артерія гомілки & 13 & 13 & 100 \\
\hline ТПС+дві артерії гомілки & 4 & 4 & 55,0 \\
\hline ТПС+три артерії гомілки & 2 & 20 & 95,2 \\
\hline Одна артерія гомілки & 21 & 16 & 94,1 \\
\hline Дві артерії гомілки & 17 & 2 & 75,0 \\
\hline Три артерії гомілки & 3 & 82 & 94,3 \\
\hline Загалом & 87 & & \\
\hline \hline
\end{tabular}


Таблиця 2. Залежність результатів втручань від характеру ураження артерій

\begin{tabular}{||l|c|c|c||}
\hline \multicolumn{1}{|c|}{ Характер ураження } & Кількість втручань & Кількість успішних втручань & Успішних втручань (\%) \\
\hline Стеноз & 59 & 57 & 96,6 \\
\hline Оклюзія & 28 & 24 & 85,7 \\
\hline Загалом & 87 & 82 & 94,3 \\
\hline \hline
\end{tabular}

Після ангіопластики значення Тср0 ${ }_{2}$ збільшилося сидячи до 52,8 $\pm 4,7$; лежачи до $31,4 \pm 3,6$. Приріст Тср0 в середньому склав $25,2 \pm 0,5(\mathrm{p}=0,012)$.

У ранньому післяопераційному періоді ампутація була виконана в одному випадку $(1,2 \%)$, що пов'язано із розвитком гострого тромбозу. Летальних випадків у ранні терміни спостереження не було. Аналіз результатів лікування пацієнтів терміном до 12 місяців показав, що прохідність артерій через 1, 6, 12 місяців становила відповідно - 90,0 \%; 64,3 \% та 40,0 \%. Ці результати свідчать, що ізольовані ураження артерій малого діаметра $€$ несприятливим фактором, що впливає на результати реконструктивних втручань, а хворі в перший рік після ангіопластики за необхідності підлягають превентивному ендоваскулярному втручанню.

Висновки. 1. Застосування ендоваскулярних втручань при СОУ артерій гомілки призводить до відновлення прохідності артерій і безпосереднього клінічного успіху в 94,3 \% спостережень.

2. Несприятливими чинниками, що впливають на клінічний результат операції з приводу СОУ при СДС, є комбіноване ураження артерій гомілки та протяжність ураження артерій більше 5 см.

3. Показання до виконання БАП можуть бути розширені при багаторівневих СОУ артерій у хворих з ішемічною формою СДС та КIHК у випадках неможливості виконання відкритої реконструкції через тяжку супутню патологію, відсутності пластичного матеріалу або поширених трофічних змінах ураженої кінцівки.

Перспективи подальших досліджень. При проведенні ендоваскулярних реваскуляризуючих оперативних втручань у пацієнтів із поєднаним СОУ доцільно дослідити ризики виникнення синдрому реперфузії-реоксигенації.

\section{СПИСОК ЛІТЕРАТУРИ}

1. Внутрішньотканинний електрофорез ізокету в комплексному лікуванні хворих на облітеруючий атеросклероз: вплив на системний коагуляційний потенціал / А. Г. Іфтодій, В. Б. Рева, О. Б. Русак [та ін.] // Український журнал екстремальної медицини ім. Г. О. Можаєва. - 2018. - Т. 19 (3). - C. 12-15.

2. The quality of guidelines for diabetic foot ulcers: A critical appraisal using the AGREE II instrument / P. Zhang, Q. Lu, H. Li [et al.] // PLoS One. - 2019. - Vol. 14 (9). e0217555. doi: 10.1371/journal.pone.0217555.

3. IWGDF guidance on the diagnosis, prognosis and management of peripheral artery disease in patients with foot ulcers in diabetes / R. J. Hinchliffe, J. R. Brownrigg, J. Apelqvist [et al.] // Diabetes/ Metabolism Research and Reviews. - 2016. - Vol. 32, Suppl. 1. P. 37-44. Epub 2015/09/04. 10.1002/dmrr.2698.

4. IWGDF guidance on use of interventions to enhance the healing of chronic ulcers of the foot in diabetes / F. L. Game, C. Attinger, A. Hartemann [et al.] // Diabetes Metabolism Research and Reviews. - 2016. - Vol. 32, Suppl. 1. - P. 75-83. Epub 2015/09/06. 10.1002/dmrr.2700.

5. Морфологічні зміни при синдромі діабетичної стопи / Р. І. Сидорчук, О. Й. Хомко, В. Б. Рева [та ін.] // Клінічна хірургія. - 2017. - Т. 10 (906). - С. 44-45.

6. How to do a 3-minute diabetic foot exam / J. D. Miller, E. Carter, J. Shih [et al.] // J. Fam. Pract. - 2014. - Vol. 63. P. 646-649, 653-656.

7. The management of diabetic foot: A clinical practice guideline by the Society for Vascular Surgery in collaboration with the American Podiatric Medical Association and the Society for Vascular Medicine / A. Hingorani, G. M. LaMuraglia, P. Henke [et al.] // Journal of Vascular Surgery. - 2016. - Vol. 63 (Suppl. 2). - P. 3s-21s. Epub 2016/01/26. 10.1016/j.jvs.2015.10.003.

\section{REFERENCES}

1. Iftodii, AH., Reva, W.B., Rusak, O.B., Silver, I.M., Reva, T.V., \& Sydorchuk, R.I. (2018). Vnutrishniotkanynnyi elektroforez izoketu v kompleksnomu likuvanni khvorykh na obliteruiuchyi ateroskleroz: vplyv na systemnyi koahuliatsiinyi potentsial [Intracellular isokette electrophoresis in the multimodal treatment of patients with obliterating atherosclerosis: influence on systemic coagulation potential]. Ukrainskyi zhurnal ekstremalnoi medytsyny im. H.O. Mozhaieva - Ukrainian Journal of Extreme Medicine named after H.O. Mozhaiev, 19(3), 12-15 [in Ukrainian]. 2. Zhang, P., Lu, Q., Li, H., Wang, W., Li, G., Si, L., \& Ding, Y. (2019). The quality of guidelines for diabetic foot ulcers: A critical appraisal using the AGREE II instrument. PLoS One, 14 (9). e0217555. doi: 10.1371/journal.pone.0217555.

3. Hinchliffe, R.J., Brownrigg, J.R., Apelqvist, J., Boyko, E.J., 
Fitridge, R., Mills, J.L., et al. (2016). IWGDF guidance on the diagnosis, prognosis and management of peripheral artery disease in patients with foot ulcers in diabetes. Diabetes/metabolism Research and Reviews, 32 (1), 37-44. Epub 2015/09/04. 10.1002/ dmrr.2698.

4. Game, F.L., Attinger, C., Hartemann, A., Hinchliffe, R.J., Londahl, M., Price, P.E., et al. (2016). IWGDF guidance on use of interventions to enhance the healing of chronic ulcers of the foot in diabetes. Diabetes Metabolism Research and Reviews, 32 (1), 75-83. Epub 2015/09/06. 10.1002/dmrr.2700.

5. Sydorchuk, R.I., Khomko, O.J., Reva, V.B., Polianskyi, O.I., Sydorchuk, L.P., \& Popovych, A.I. (2017). Morfolohichni zminy pry syndromi diabetychnoi stopy [Morphological changes in diabetic foot syndrome]. Klinichna khirurhiia - Clinical Surgery, 10 (906), 44-45 [in Ukrainian].

6. Miller, J.D., Carter, E., \& Shih, J. (2014). How to do a 3-minute diabetic foot exam. J. Fam. Pract., 63, 646-649, 653-656.

7. Hingorani, A., LaMuraglia, G.M., Henke, P., Meissner, M.H., Loretz, L., Zinszer, K.M., et al. (2016). The management of diabetic foot: A clinical practice guideline by the Society for Vascular Surgery in collaboration with the American Podiatric Medical Association and the Society for Vascular Medicine. Journal of Vascular Surgery, 63 (2 Suppl), 3s-21s. Epub 2016/01/26. 10.1016/j.jvs.2015.10.003.

Отримано 01.11.2019

Електронна адреса для листування: sydorchuk.r@bsmu.edu.ua

V. P. POLYOVYY, BILEL KHORSHANI, O. Y. KHOMKO, R. I. SYDORCHUK, P. M. VOLJANJUK, I. I. BILYK

Bukovinian State Medical University, Chernivtsi

\title{
ENDOVASCULAR SURGICAL INTERVENTIONS FOR THE CORRECTION OF CRITICAL LOWER LIMB ISCHEMIA IN DIABETIC FOOT SYNDROME
}

\begin{abstract}
The aim of the work: to analyze the possibilities of endovascular correction of stenotic-occlusive lesions of the arteries of the poplitealankle-foot segment with diabetic foot syndrome and critical lower limb ischemia.

Materials and Methods. The study is based on the analysis of the results of clinical observation and treatment of 87 patients with diabetic foot syndrome with stenotic-occlusive lesions of the arteries of the popliteal and foot-segment and development of critical limb ischemia (mean age (67.3 \pm 8.35 years). The main indication for endovascular arterial intervention was lower limb ischemia degree 4 by Fontaine. The criterion for evaluating the effectiveness of surgery in this study was considered to be residual stenosis less than 30 . Results and Discussion. The use of endovascular interventions for stenotic-occlusive lesions of the arteries of the lower leg leads to the restoration of patency of the arteries and immediate clinical success in $94.3 \%$ of observations. Adverse factors affecting the clinical outcome of the operation are the combined lesion of the arteries of the lower leg and the length of the lesions of the arteries more than $5 \mathrm{~cm}$. pathology, lack of plastic material or common trophic changes in the affected limb.
\end{abstract}

Key words: diabetic foot syndrome; stenotic-occlusive vascular lesions; endovascular surgery; balloon angioplasty; critical lower extremity ischemia.

\section{ЭНДОВАСКУЛЯРНЫЕ ОПЕРАТИВНЫЕ ВМЕШАТЕЛЬСТВА ДЛЯ КОРРЕКЦИИ КРИТИЧЕСКОЙ ИІІЕМИИ НИЖНИХ КОНЕЧНОСТЕЙ ПРИ СИНДРОМЕ СТОПЫ ДИАБЕТИКА}

\begin{abstract}
Цель работы: проанализировать возможности эндоваскулярной коррекции стенотически-окклюзионных поражений артерий подколенно-голенно-стопового сегмента при синдроме стопы диабетика и критической ишемии нижних конечностей. Материалы и методы. Исследование базируется на анализе результатов клинического наблюдения и лечения 87 больных с синдромом стопы диабетика с стенотически-окклюзионным поражением артерий подколенно-голенно-стопового сегмента и развитием критической ишемии нижних конечностей (средний возраст $(67,3 \pm 8,35)$ года). Основным показанием к выполнению эндоваскулярных артериальных вмешательств была ишемия нижней конечности IV ст. по Fontaine. Критерием оценки эффективности оперативного вмешательства в данном исследовании считали остаточный стеноз менее 30.

Результаты исследований и их обсуждение. Применение эндоваскулярных вмешательств при стенотически-окклюзионных поражениях артерий голени приводит к восстановлению проходимости артерий и непосредственного клинического успеха в 94,3 \% наблюдений. Неблагоприятными факторами, влияющими на клинический исход операции, является комбинированное поражение артерий голени и протяженность поражения артерий более 5 см. Показания к выполнению баллонной ангиопластики могут быть расширены при многоуровневых окклюзиях артерий у больных с ишемической формой стопы диабетика в случаях невозможности выполнения открытой реконструкции из-за тяжелой сопутствующей патологии, отсутствии пластического материала или распространенных трофических изменениях пораженной конечности.
\end{abstract}

Ключевые слова: синдром стопы диабетика; стенотически-окклюзионные поражения сосудов; эндоваскулярные оперативные вмешательства; баллонная ангиопластика; критическая ишемия нижних конечностей. 